\title{
中国東北地方における土地流転からみた農村集落の類型化とその計画課題 一遼寧省瀋陽市瀋北新区・尹家街道を事例に一 \\ STUDY ON THE DIFFERENTIATION OF VILLAGE TYPES AND PROBLEMS ON VILLAGE PLANNING BASED ON FARMLAND LIQUIDITY IN NORTHEAST CHINA
}

- A case study of yinjia sub district in shenbei new district, shenyang city, liaoning province -

$$
\begin{aligned}
& \text { 張 然*1, 山崎 寿一 }{ }^{* 2} \\
& \text { Ran ZHANG and Juichi YAMAZAKI }
\end{aligned}
$$

\begin{abstract}
This paper aims to clarify the tendency of village differentiation in a township based on farmland liquidity, and put forward the village planning problems to be faced in the future in Northeast China. Taking Yinjia Subdistrict as an object for research, it is found that, in 2016, about 80 percent of farmers lent part or all their land to other agricultural operators. And based on the type of major borrowers, all the 15 villages can be divided into three types, "Absorption within the village type", "Lending to operators outside the village type", and "Agricultural company intervention type".
\end{abstract}

Keywords: Northeast China, Farmland liquidity, Differentiation of village types, Township, Planning problems 中国東北地方, 土地流転, 集落の類型化, 郷級行政区, 計画課題

\section{1. 研究の背景 · 目的}

\section{1 研究の概要 ·目的}

中国では、1980 年代半ばより、農村人口の都市流出に伴い、農村 の土地流転注1)が展開されてきた。近年、土地流転が活発化してきて おり、2016 年 6 月現在、全国の農家が請負った農地(以下、「請負農 地」と省略)の内、1/3 以上(約 3067 万 ha) でその経営権の流通が行 なわれた(韓長賦、中国農業農村部部長) 注 2)。そのため、農村集落の 空間形成の基礎となる土地利用は重大な転換点を迎えており、土地 利用の展開から集落の空間構造を再認識し、今後の計画課題を把握 寸ることが重要であり、課題となっている。

本稿は、中国東北地方における土地利用からみた農村集落の空間 形成及びその構造の変化に関する一連の研究の第一報である。ここ では、遼寧省瀋陽市瀋北新区主3)・尹家街道を対象に、郷級行政区域 (日本の地方自治体の町に相当する。以下、「郷域」と省略) 注4)におけ る農村集落の土地流転の実態及びその仕組みを把握し、集落の類型 の特性及び今後の計画課題を明らかにすることを目的とする。尚、 類型別の集落の社会空間構造とその計画課題に関しては、次稿から 報告する予定である。

\section{2 中国農村の土地制度の変遷と土地流転の展開}

中国農村の土地制度は、新中国成立後、劇的な变化を遂げてきた。 新中国成立前後の土地改革(1945-1953)により、従前の封建的・半 封建的地主制度は廃止され、「耕者有其田(耕作者がその土地を有す る)」が実現された。その後、ただちに農村の社会主義的改造が始ま り、農業合作化期(1953-1957)の「土地私有、合作化経営」、人民公
社期(1958～1983)の「集団所有・集団経営」を経て、さらに改革開 放政策の実施に伴い、集団所有制をべースとする「家族請負経営制」 が導入された。現在、農村部の農地・宅地は農家集団(村民小組、村、 郷・鎮)の所有権により所有され、その請負経営権・利用権は個々の 在籍農家(該当集落の農業戸籍を持つ農家)に分配された(いわゆる、 土地権利の二権分離)。

一方、改革開放政策実施後は、農家人口の都市流出に伴い、総人 口に占める農村部の常住人口の割合が 1978 年の $82.08 \%$ (7.9 億人) から 2017 年の $41.48 \%$ (5.8 億人)まで減少し(中国統計年鑑 2018)、 農村部の人口減少・労働力不足の進展に伴い、土地流転と新たな担 い手の育成が求められるようになった。

土地流転の促進を巡る農村土地制度の改革は、1980 年代半ばよ り始まり、1993 年以降、ほぼ毎年度のように関連制度・法令条文が 打ち出され続けており、その重要な転換点は概ね Table 1 に整理で きる。(1)1984 年-1993 年に、禁止であった土地流転の制限緩和が始 まった。この時期、主に経済成長の著しい地域(北京、天津、上海、 蘇南地区、珠江デルタなど)では、郷鎮企業の急速な発展に伴う農民 の営農意欲の減退に応じて、土地流転が展開されてきた。(2)1993 年 -2008 年に、土地流転が法律(農業法、1993 年実施)で認められ、そ の取扱いも徐々に明確化されてきた。この時期、出稼ぎ労働者の増 加に伴い全国各地で土地流転が展開されてきたが、全体として農民 の土地流転の意欲はまだ低く、大規模な土地流転と先進的な農業技 術の導入を行う地区は少なかった 1)。2008 年時点での全国の土地流 転比率は $8.07 \%$ であった注 5)。(3)2008 年以降、土地流転市場の建設
*1 神戸大学工学研究科建築学専攻 博士後期

*2 神戸大学工学研究科建築学専攻 教授. 博士 (工学)
Ph.D. Candidate, Graduate School of Eng., Kobe Univ.

Prof., Graduate School of Eng., Kobe Univ., Dr.Eng. 
Table1 The Development of Policies and Laws on Rural Land Liquidity 土地流転に関する制度・法律条文の展開

\begin{tabular}{|c|c|c|c|c|}
\hline \multicolumn{2}{|c|}{ Time } & Policy \& Law & Associated contents & Government \\
\hline \multirow{4}{*}{ 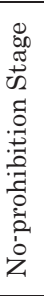 } & 1984.1 & Notice on Rural Work in 1984 & Encouraging the gradual centralization of land to farming experts. & $\begin{array}{l}\text { CPC Central } \\
\text { Committee }\end{array}$ \\
\hline & 1986.1 & $\begin{array}{l}\text { Deployment of Rural Work in } \\
1986\end{array}$ & $\begin{array}{l}\text { With the transfer of farmers to non-agricultural industries, } \\
\text { farmland should be encouraged to centralized to farming experts. }\end{array}$ & $\begin{array}{l}\text { CPC Central } \\
\text { Committee }\end{array}$ \\
\hline & 1987.1 & Deepening Rural Reform & $\begin{array}{l}\text { Farmers who engage in other occupations for a long time and do } \\
\text { not cultivate land themselves, shall return the contracted land to the } \\
\text { collective or subcontract it to others with the collective consent in } \\
\text { principle. }\end{array}$ & $\begin{array}{l}\text { Political Bureau of } \\
\text { the CPC Central } \\
\text { Committee }\end{array}$ \\
\hline & 1988.4 & Constitutional Amendment & $\begin{array}{l}\text { The use right of land can be transferred in accordance with the } \\
\text { provisions of the law. }\end{array}$ & $\begin{array}{l}\text { National People's } \\
\text { Congress }\end{array}$ \\
\hline \multirow{4}{*}{ 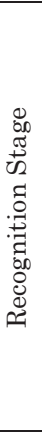 } & 1993.7 & Agricultural Law & Land contractors have the right to transfer the land use right. & $\begin{array}{l}\text { National People's } \\
\text { Congress }\end{array}$ \\
\hline & 1993.11 & $\begin{array}{c}\text { Decision on Several Issues } \\
\text { Concerning the Establishment } \\
\text { of Socialist Market Economy } \\
\text { System }\end{array}$ & Allowing paid transfer of land use right according to law. & $\begin{array}{l}\text { CPC Central } \\
\text { Committee }\end{array}$ \\
\hline & 1994.12 & $\begin{array}{l}\text { Opinions on Stabilizing and } \\
\text { Perfecting Land Contracting } \\
\text { Relations }\end{array}$ & $\begin{array}{l}\text { Adhering to collective ownership, not changing the use of land for } \\
\text { agriculture, and the party awarding contract agree, contractor can } \\
\text { subcontract, transfer, exchange or share the contracted land in } \\
\text { accordance with the law during the contracting period. }\end{array}$ & $\begin{array}{l}\text { Ministr } \\
\text { Agricul }\end{array}$ \\
\hline & 2005.3 & $\begin{array}{c}\text { Management Measures on the } \\
\text { Transfer of Rural Land } \\
\text { Contractual Management } \\
\text { Right }\end{array}$ & $\begin{array}{l}\text { Adhering to the household contractual management system and } \\
\text { stabilizing the contractual relationship of rural land, the transfer of } \\
\text { contractual management right of rural land should follow the } \\
\text { principles of equal consultation, legality, voluntariness and } \\
\text { compensation. }\end{array}$ & $\begin{array}{l}\text { CPC Central } \\
\text { Committee and } \\
\text { The State Council }\end{array}$ \\
\hline \multirow{4}{*}{ 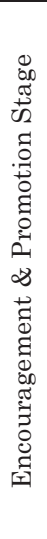 } & 2008.10 & $\begin{array}{l}\text { Decision on Several Major } \\
\text { Issues in Promoting Rural } \\
\text { Reform and Development }\end{array}$ & $\begin{array}{l}\text { Strengthen the management and service of the transfer of rural } \\
\text { land contractual management right, and establish the market for the } \\
\text { transfer of rural land contractual management right } \cdots \text { and develop } \\
\text { various forms of moderate scale management. }\end{array}$ & $\begin{array}{c}\text { CPC Central } \\
\text { Committee and } \\
\text { The State Council }\end{array}$ \\
\hline & 2012.2 & $\begin{array}{c}\text { Some Opinions on Accelerating } \\
\text { the Innovation of Agricultural } \\
\text { Science and Technology and } \\
\text { Continuous Enhancement of } \\
\text { Agricultural Product Supply } \\
\text { Capacity }\end{array}$ & $\begin{array}{l}\text { Strengthen the management and service of the transfer of rural } \\
\text { land contractual management right, and improve the arbitration } \\
\text { system of land contractual management disputes mediation. }\end{array}$ & $\begin{array}{l}\text { CPC Central } \\
\text { Committee and } \\
\text { The State Council }\end{array}$ \\
\hline & 2013.11 & $\begin{array}{l}\text { The Decision on Major Issues } \\
\text { Concerning Comprehensively } \\
\text { Deepening Reforms }\end{array}$ & $\begin{array}{l}\text { Encourage the transfer of rural land management right to large } \\
\text { professional households, family farms, farmers' cooperatives and } \\
\text { agricultural enterprises in the open market, and develop various } \\
\text { forms of large-scale operation. }\end{array}$ & $\begin{array}{l}\text { CPC Central } \\
\text { Committee }\end{array}$ \\
\hline & 2014.11 & $\begin{array}{l}\text { Opinions on Guiding the } \\
\text { Orderly Transfer of Rural } \\
\text { Land Management Right and } \\
\text { Developing Moderate Scale } \\
\text { Agriculture }\end{array}$ & $\begin{array}{l}\text { Adhere to the collective ownership of rural land, realize the } \\
\text { separation of ownership, contractual right and management right, } \\
\text { and guide the orderly circulation of land management right. }\end{array}$ & $\begin{array}{l}\text { CPC Central } \\
\text { Committee and } \\
\text { The State Council }\end{array}$ \\
\hline
\end{tabular}

Note: CPC Central Committee is short for the Central Committee of the Communist Party of China.

及び関連サービスの強化が推し進められるようになった。同時に、 農民専業合作社(以下、「合作社」と省略)、大規模専業農家 (以下、「大 規模農家」と省略)、家庭農場、龍頭企業などの新たな担い手像が提 示され、新たな担い手への農地集積の支援が明確化した。さらに、 2013 年 11 月に中国共産党第 18 期中央委員会第 3 回全体会議後、 土地流転の方針が明確化され、農地の「所有権、請負権、経営権を 分離した上で、経営権の流通を可能にすること」(2014.11)が提出さ れた(いわゆる、土地権利の三権分離)。この時期、農家の農外収入 の増加に伴う土地流転が加速し、2016 年には全国の土地流転の比 率は $35.1 \%$ まで増加した。

このように、在籍農家の離農離村と土地流転の進展に伴い、集落 の農地経営の実態と担い手像が大きく変わり、集落の展開方向と今 後の計画課題を再認識することが重要な課題となっている。

\section{3 既往研究の動向と本研究の新規性}

中国における都市と農村計画学(中国語、「城郷規劃学」と呼ばれ る)の展開は 2 段階に分けられる(袁奇峰, 中山大学教授、2012)。 2010 年以前では、建築学分野の下で位置づけられ、都市計画学(中 国語、「城市規劃学」) と呼ばれ、国の社会・経済発展及び行政側の 都市開発・都市管理の意図に対応した都市空間を作ることが主な役 割であった。2011 年に、建築学分野から独立し、都市と農村計画学
に改称され、そのもとで、農村計画分野が設置された 2)。そのため、 農村計画分野の展開が遅れており、集落空間の認識論や集落計画研 究の方法論が未確立となっているのが現状である注 6)。

一方、中国農村の土地流転に関する中国及び日本での研究は、 2000 年以降に活発化しており、主に農業経済学、農政学等の分野で 行われている。

中国では、地方、省・市・県、市管轄区注 7)内の広域な農村部を対 象として扱い、土地流転を地区の社会・経済状況、発展戦略、土地 流転市場の建設状況、行政側の管理意識などと結び付けて、土地流 転の仕組みや、地域間の差異及びその影響要素等を考察するものが 多くみられた。楽章(中南財経政法大学、教授、2010)、黄祖輝(浙江 大学中国農村発展研究所、教授、2008)、包宗順(江蘇省社会科学院 農村発展研究所所長、2009)らにより、東部沿海地域、大都市近郊農 村地域、一部の人口流出が激しい農村地域では、土地流転の市場化 及びその仕組みの多様化(転包、出租、互換転譲、反租倒包、股份合 作、その他)が活発に展開されている一方、第二次・第三次産業の発 展が遅れている地域や社会保障が低い農村地域では、農家間の無償 の賃貸借が主流であることがわかった 1)344)。また、梅琳(福建師範大 学、博士、2011)により、上海松江の“家庭農場”モデル、温州の“食糧 大戸”モデル、山東寧陽の“株式十合作”モデル、福建三明の“請負経営 
権抵当”モデル等、各地で地元の状況に応じた土地流 転の仕組みが創られたことがわかった5)。しかし、集 落計画分野の展開が遅れているため、集落の土地流 転に関する研究は緒に就いた段階である。

日本では、中国の農村集落の土地流転に関する若 干の研究が発表された。その中でも、東北地方の朝鮮 族集落を対象とするものが多くみられた。李英花 $($ 新 潟大学大学院、2011)、金紅蘭(岩手大学大学院連合農 学研究科、2013)、李雪蓮(北海道大学大学院農学院、 2016)らにより、1990 年代以降、朝鮮族の離農比率 が高まり主 8)、離農跡地の在村農家又は周辺集落の農 家への集積が活発になっていることが分かった 6)-8)。 精緻な調查に基づき、集落の土地流転の実態・特徵を 分析した研究であるが、集落を地域の中に位置づけ て、地域の性格が集落の土地流転に与えた影響や、地 域における集落の位置付けの変化に着目寸る視点が 希薄である。

そこで本研究は、集落を郷域の中に位置付けて、郷 域における集落の土地流転の実態及びその仕組みを 考察し、集落の類型の特性及び今後の計画課題を検 討する。

本研究の課題設定の特徴とその新規性・意義について、次の 2 点 が挙げられる。

(1)「集落単位の土地流転」に着目すること：従来人民公社期の集 落では、「戸籍制度」と「農村土地集団所有制」という二つの相補的 な制度のもと、在籍農家は集落の土地に束縛され、農業の共同経営 に専念し、地域間の自由な移動ができなかった。人民公社解体後、 在籍農家は農地の請負経営権を獲得した一方、戸籍制度の制限も緩 和され、離農離村が徐々に展開されてきた。その後、離農離村の増 加と土地流転の展開に伴い、離農跡地は主に残る在籍農家によって 吸収される集落や、離農跡地は主に集落外の主体(農家、合作社、企 業など)に貸出される集落や、耕作放棄地問題に懸念がある集落など、 在籍農家及び非在籍主体と集落の農業・農地との関わり方が多様化 してきた。これらの変化は、集落の社会空間構造の変化をもたらし、 集落の再整備計画課題や集落運営課題に重要な影響を与えることが 考えられる。

その意味で、土地流転を集落単位で捉えることは、集落の社会空 間構造を再認識し、集落の計画課題を押さえることに意義がある。

(2)集落を「郷域」の中に位置付けて考察すること：中国における 従来の集落域レベルの計画は「集落計画」(空間計画、建設計画) と

「集落土地利用計画」(主要な内容は線引きと用途規制)の 2 つ分 かれており、「城郷計画法」(2008 年 1 月実施) と「土地利用総体計 画管理弁法」(2017 年 5 月実施、2019 年 7 月廃止)によって、いず れも郷級人民政府の主導のもとで策定される。2019 年 5 月に公布 された「自然資源部弁公庁関於加強村庄規劃促進鄉村振興的通知」 では、「集落土地利用計画、集落建設計画などの郷村計画を整合させ て...『多規合一』(多数の計画を一つにまとめる)の実用性集落計画を 策定する」ことが提出された。同じように、「集落計画は郷(鎮)政府 の主導のもとで編制すること」が明記された(第 19 条)。また、2014 年 11 月に公布された中共中央弁公庁、国務院の「関于引導農村土地

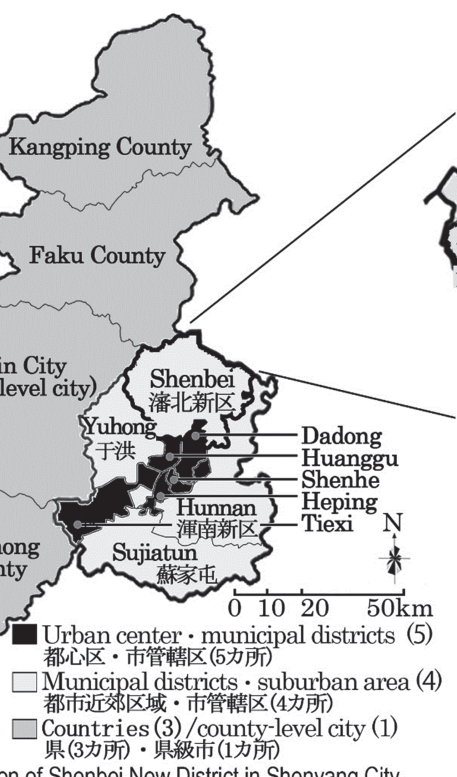

(3力所) ・ 県級市( 1 力所)

瀋北新区の位置

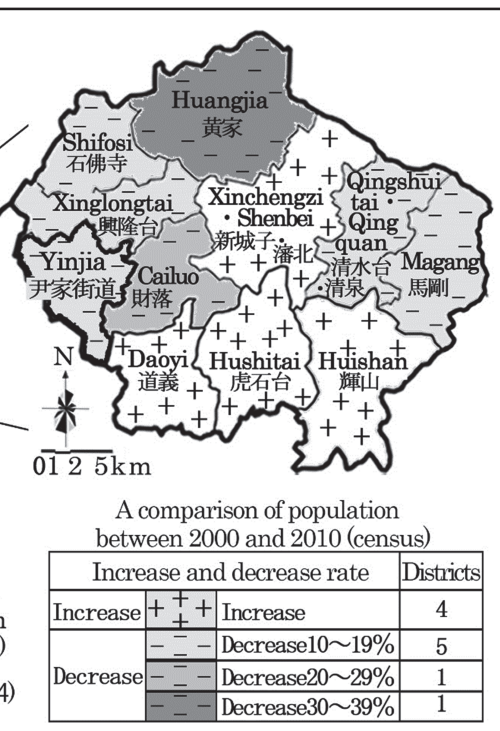

(2) Location of Yinjia Subdistrict in Shenbei New District 口増堿と尹家街道の位置

$$
\text { 瀋陽市瀋北新区・尹家街道の位置 }
$$

経営権有序流転発展農業適度規模経営的意見」では、「土地流転に関 する管理とサービスを強化し...県・郷・村三級のサービスと管理の ネットワークを完備させること」(第 7 条)が強調された。

このように、集落を郷域の中に位置付けて考察することは、郷級 人民政府による集落計画の策定や、土地流転に関する適切なサービ スと管理を提供することにおいて、参考になると言える。

\section{2 研究対象と研究方法}

\section{1 研究対象}

\subsection{1 対象地域の展開及びその特性}

瀋北新区は、瀋陽市の市区の北部に位置する一つの市管轄区であ り、11 街道によって構成される(Fig.1)。

瀋北新区では、 7000 年前の中国の新石器時代から人間の活動が展 開され、原住民は遊牧民、半農半遊・半遊半猟・半漁半猟民であり、 農耕民の定住文化の広がりが遅かった。「瀋陽地名・潘北新区巻」で 収録されている 168 集落の内、18 集落は清朝以前に形成され、140 集落は清朝(1636-1912)に形成され、そのほとんどは漢民族、満民族、 シボ族、モンゴル族の集落である。人民公社期には、畑地の水田化 と稲作を行うために、1970 年代に東北地方の各地からの朝鮮族の入 植が行なわれ、10 力所の朝鮮族集落が開発された(Table 2)9)。

尹家街道は瀋北新区の農業地域に位置する 1 つの街道であり、清 朝の「闖関東」注 9)により形成された 12 力所の漢民族集落(茨榆坨、

Table2 Formation Period of Villages in Shenbei New District 瀋北新区の既存集落の形成時期

\begin{tabular}{l|c|cc}
\hline \multicolumn{1}{c}{ Formation Period } & Number & General situation \\
\hline $\begin{array}{l}\text { Before Qing Dynasty } \\
\text { 清朝前 }\end{array}$ & 18 & $\begin{array}{l}\text { Song Dynasty (960-1279) } \\
\text { Yuan Dynasty (1271-1368) } \\
\text { Ming Dynasty (1368-1644) 15 }\end{array}$ \\
$\begin{array}{l}\text { Qing Dynasty 清朝 } \\
\text { (1636-1912) }\end{array}$ & 140 & $\begin{array}{c}\text { The hamlets of the Han, Man, } \\
\text { Xibo, Mongols Nationalities }\end{array}$ \\
$\begin{array}{l}\text { After the foundation of } \\
\begin{array}{l}\text { New China(1970s) } \\
\text { 新中国成立後 }\end{array}\end{array}$ & 10 & $\begin{array}{c}\text { The hamlets of the Korean } \\
\text { Nationality }\end{array}$ \\
\hline
\end{tabular}




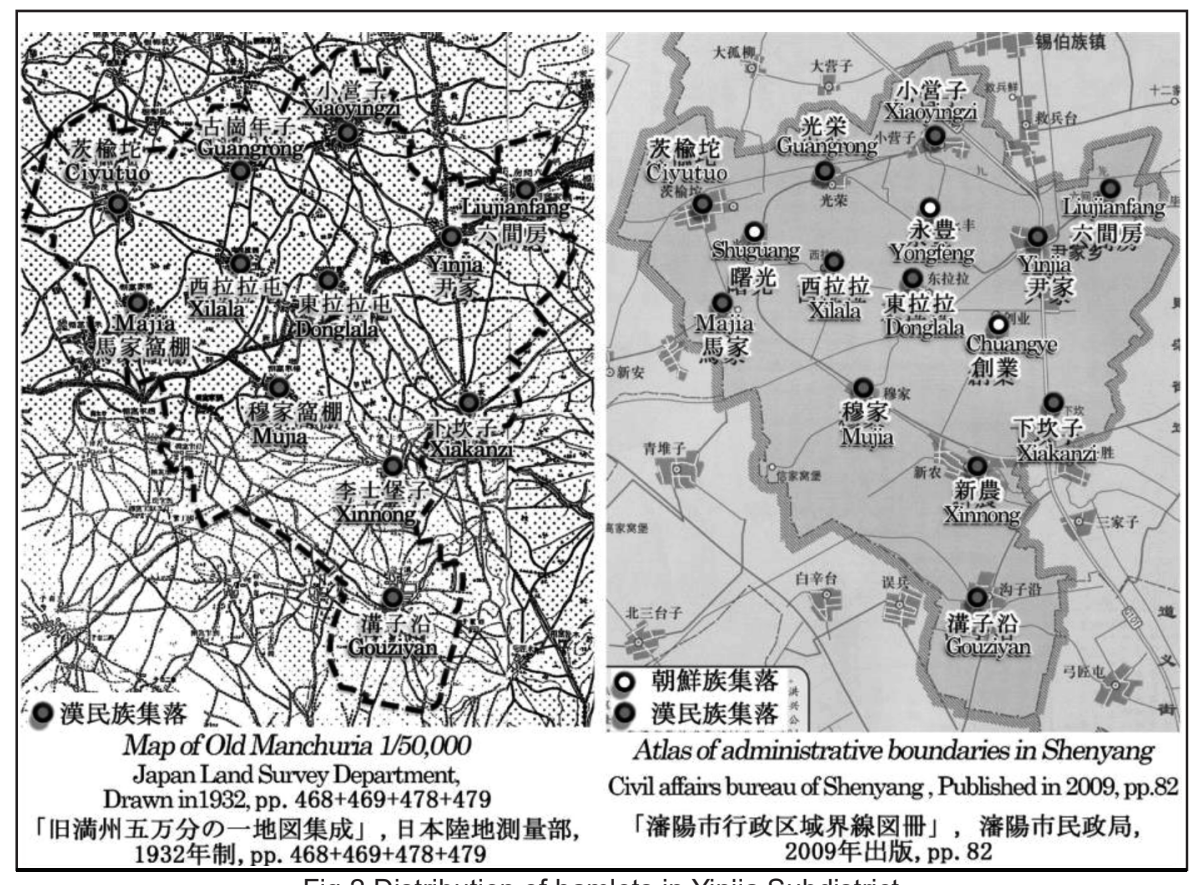

Fig.2 Distribution of hamlets in Yinjia Subdistrict 尹家街道の集落の分布

モデル地区）の合併によって形成され、都 市開発事業を推進すると同時に、都市農業 モデル地区と農産物加工業の基地を創設 する目標も設定されたのが特徵的である。 瀋北新区では、 2009 年に遼寧省に先駆けて 大規模な土地流転が展開され、2017 年 8 月 現在、80\%以上の請負農地の集積と大規模 経営が実現された注 10 。

(2)尹家街道では、大規模農家、合作社、 農業企業などの新たな担い手の農業参入 が展開され、集落の土地利用方式の選択肢 が多様化しており、集落の類型化を考察し やすい。

\section{2 研究方法}

\subsection{1 農村集落の類型の定義}

本稿では、集落における土地流転の方式 と主な借り手のタイプによって、集落を下 記の 3 種類に分ける。

(1)「集落内集積型」: 離農跡地は主に集落 内の在籍農家或いは合作社によって吸収

馬家、光栄、小営子、東拉拉、西拉拉、尹家、六間房、穆家、下坎 子、溝子沿、新農) と人民公社期に開発された 3 力所の朝鮮族集落(曙 光、永豊、創業)によって構成される(Fig.2)。

一方、改革開放から 2000 年まで、潘北新区はほぼ純農業地域で あり 10)、総人口の増加は明らかではなかった。2000 年以降に、南 部の 3 街道(道義、虎石台、輝山) と中央部の 1 街道(新城子)では、都 市開発事業の展開に伴う人口集積が見られ、総人口の増加が目立っ てきた一方で、尹家街道を含む 7 街道では、従来と変わらず、農業 が主要な生業となる地域であり、人口減少が著しくなってきている (Fig.1(2)、Table 3)。

\section{1 .2 対象地域の選定理由}

瀋陽市瀋北新区・尹家街道を対象とする理由は下記の 2 つある。 (1)瀋北新区は、2006 年に国務院民政部の同意の上で、「新城子区」 と「輝山農業高新技術開発区」(2002 年に成立された農業技術開発

Table 3 Population increase and decrease in Yinjia Subdistrict, Shenbei New District 瀋北新区・尹家街道の人口の増減

\begin{tabular}{c|c|c|c|c|c}
\hline & & 1982 & 1990 & 2000 & 2010 \\
\hline & $\begin{array}{c}\text { Total population } \\
\text { 総人口 }\end{array}$ & 279345 & 304038 & 304230 & 423323 \\
$\begin{array}{c}\text { Shenbei } \\
\text { New } \\
\text { District } \\
\text { 潘北新区 } \\
\text { 家庭戸の総戸数 } \\
\text { Total population } \\
\text { of family households } \\
\text { 家庭戸の総人口 }\end{array}$ & $/$ & $/$ & 94780 & 119590 \\
\hline $\begin{array}{c}\text { Total population } \\
\text { 総人口 }\end{array}$ & 14873 & $/$ & 13760 & 11714 \\
$\begin{array}{c}\text { Yinjia } \\
\text { Fambistrict } \\
\text { 尹家街道 } \\
\text { 家庭戸の総戸数 } \\
\text { Total population } \\
\text { of family households } \\
\text { 家庭戸の総人口 }\end{array}$ & $/$ & $/$ & 4072 & 4155 \\
\hline
\end{tabular}

Notes: 1) Refer to "Compilation of Manual Data of the Third Population Census in Shenyang, Liaoning Province, 1982", "Compilation of Manual Data of the Fourth Population Census in Liaoning Province, 1990", " the Fifth Census Data,2000", "the Sixth Census Data,2010". 2) The total population includes family household population and collective household population.
された集落である。(2)「集落外貸出型」: 離農跡地は主に集落外の農 家或いは合作社に貸出された集落である。(3)「企業参入型」: 離農跡 地は主に企業に貸出された集落である。

「土地流転の方式」について、集落内部の在籍農家への土地流転 は「転包」(下請け)と呼ばれ、集落外の非在籍主体への土地流転は 「出租」(賃貸)と呼ばれる。従って、(1)「集落内集積型」集落の土地 流転の主な方式は「転包」であり、(2)「集落外貸出型」集落と(3)「企 業参入型」集落の土地流転の主な方式は「出租」である。

「借り手」について、尹家街道では、「合作社」は主に街道内の 1 戸から数戸の農家によって運営され、大規模農業経営を従事すると 同時に、田植え、農作物の種まき、収穫などの機械化サービスを提 供する。そして、借り手が合作社の場合、農地の経営の方式とその 空間的形態は、借り手が農家の場合とほぼ変わらない。そのため、 本稿では、農家と合作社をまとめて1タイプとしている注 11$)$ 。方、 借り手が企業の場合は、一般的に高付加価值作物(花・観葉植物、野 菜など)の栽培又は家畜・家禽の繁殖、飼育を行い、ビニールハウス や牧場などの関連施設が建てられ、農地利用の空間的形態が大きく 変わった。それは、集落の景観及び今後の計画課題に影響を与える ため、別の類型とした。

\subsection{2 研究課題の内容と現地調査・資料収集}

2017 年 9 月- 11 月と 2018 年 10 月- 11 月の現地調查・資料収集で 得られた情報に基づき、以下の手順で作業を行った。

(1) 土地流転と集落の類型化の概況の把握 : 尹家街道・街道弁事処 (役場)農業科(農業に関する業務を担う部署)の農地管理部門の公務 員に対するヒアリング調查を行い、土地流転の展開経緯とその現状 を把握した。「2016 年度尹家街道・農村経済基本状況統計表」尹家 街道人民政府作成)を入手し、土地流転に関する統計データを整理し た。その後、農地管理部門で保管されている「土地流転の契約書」 注12)の閲覧を申請し、関連情報（借り手、貸し手、期間等）を整理し た(第 3 章で述べる)。 
(2)集落類型別の土地流転の仕組みの把握 : 尹家街道・街道弁事処 農業科の農地管理部門の公務員に対するヒアリング調査を行い、集 落類型別の土地流転における借り手・貸し手の属性を把握し、その 仕組みを把握した。その後、水田集落の中の集落内集積型・茨榆坨 集落、集落外貸出型 $\cdot$ 曙光集落と永豊集落、企業参入型・尹家集落 と、畑地集落の中の集落内集積型 ・溝子沿集落、集落外貸出型・新 農集落、6 集落を対象に、実際の推進状況に関する在住者ヒアリン グ調査を行った(第 4 章で述べる)。

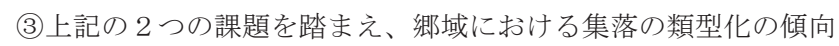
及び集落類型別の位置づけを明らかにし、今後の計画課題に関する 知見を導く(第 5 章で述べる $)$ 。

\section{3. 土地流転と集落の類型化の概況}

Table 4 と Table 5 は、街道弁事処の農業科で得られた情報をも とに、土地流転と集落の類型化に関する内容を整理したものである。

\section{1 土地流転の概況}

尹家街道では、1 集落当たり平均請負農地の面積は 3784 畧(約 250ha)であり、 1 集落当たり平均請負農家の数は 263 戸であり、 1 請負農家当たりの平均請負農地の面積は 14.1 畧(0.94ha)である。小 規模な農業経営の収入は少ないため、1990 年代から農外就業機会の 増加に伴い、離農農家が増加しつつある。

Table 4 The general situation of farmland liquidity 尹家街道における農地流動化の概況

\begin{tabular}{|c|c|c|c|c|c|c|c|c|c|c|c|}
\hline & \multirow{3}{*}{$\underset{\text { 集落 }}{\text { Hamlets }}$} & \multicolumn{6}{|c|}{$\begin{array}{c}\text { Area of contracted farmland(mu) } \\
\text { 請負農地の面積(嘼) }\end{array}$} & \multicolumn{4}{|c|}{$\begin{array}{l}\text { Peasant households } \\
\text { 請負農家 }\end{array}$} \\
\hline & & \multirow{2}{*}{$\begin{array}{c}\text { Area } \\
\text { 面積 }\end{array}$} & \multirow{2}{*}{$\begin{array}{c}\text { Paddy } \\
\text { field } \\
\text { 水田 }\end{array}$} & \multirow{2}{*}{$\begin{array}{c}\text { Dry } \\
\text { farm } \\
\text { land } \\
\text { 畑 }\end{array}$} & \multicolumn{3}{|c|}{$\begin{array}{c}\text { Land borrowed out } \\
\text { 貸出農地 }\end{array}$} & \multirow{2}{*}{$\begin{array}{l}\text { House } \\
\text { holds } \\
\text { 戸数 }\end{array}$} & \multirow{2}{*}{\begin{tabular}{|c|} 
Land for \\
each \\
household \\
1 戸当たり \\
の面積 \\
\end{tabular}} & \multicolumn{2}{|c|}{$\begin{array}{l}\text { Lenders } \\
\text { 貸し手 }\end{array}$} \\
\hline & & & & & $\begin{array}{l}\text { Area } \\
\text { 面積 }\end{array}$ & $\begin{array}{c}\mathrm{Ra} \\
\text { 比 }\end{array}$ & tio & & & $\begin{array}{l}\text { House } \\
\text { holds } \\
\text { 戸数 }\end{array}$ & $\begin{array}{c}\text { Ratio } \\
\text { 比率 }\end{array}$ \\
\hline 1 & $\begin{array}{c}\text { Shu guang } \\
\text { 曙光 }\end{array}$ & 2584 & 2584 & & 2584 & $100 \%$ & \multirow{7}{*}{ High } & 135 & 19.1 & 135 & $100 \%$ \\
\hline 2 & $\begin{array}{l}\text { Yong feng } \\
\text { 永豊 }\end{array}$ & 2976 & 2976 & & 2976 & $100 \%$ & & 231 & 12.9 & 231 & $100 \%$ \\
\hline 3 & $\begin{array}{l}\text { Chuang ye } \\
\text { 創業 } \\
\end{array}$ & 1212 & 1212 & & 1212 & $100 \%$ & & 158 & 7.7 & 158 & $100 \%$ \\
\hline 4 & $\begin{array}{c}\text { Yin jia } \\
\text { 尹家 }\end{array}$ & 3106 & 3106 & & 3000 & $97 \%$ & & 277 & 11.2 & 250 & $90 \%$ \\
\hline 5 & $\begin{array}{c}\text { Xin nong } \\
\text { 新農 } \\
\end{array}$ & 7403 & & 7403 & 7000 & $95 \%$ & & 622 & 11.9 & 550 & $88 \%$ \\
\hline 6 & $\begin{array}{l}\text { Xia kan zi } \\
\text { 下坎子 }\end{array}$ & 1498 & & 1498 & 1400 & $93 \%$ & & 177 & 8.5 & 140 & $79 \%$ \\
\hline 7 & $\begin{array}{l}\text { Dong la la } \\
\text { 東拉拉 }\end{array}$ & 2826 & 2826 & & 2442 & $86 \%$ & & 230 & 12.3 & 150 & $65 \%$ \\
\hline 8 & $\begin{array}{c}\text { Xiao ying zi } \\
\text { 小営子 }\end{array}$ & 3546 & 3546 & & 2957 & $83 \%$ & \multirow{8}{*}{$-\begin{array}{c}\text { Ratio } \\
\text { 比率 } \\
\downarrow \\
\\
\text { Low } \\
\text { 低 }\end{array}$} & 257 & 13.8 & 150 & $58 \%$ \\
\hline 9 & $\begin{array}{c}\text { Gou zi yan } \\
\text { 溝子沿 }\end{array}$ & 12576 & & 12576 & 10438 & $83 \%$ & & 570 & 22.1 & 500 & $88 \%$ \\
\hline 10 & $\begin{array}{c}\text { Guang rong } \\
\text { 光栄 }\end{array}$ & 2702 & 2702 & & 1903 & $70 \%$ & & 237 & 11.4 & 200 & $84 \%$ \\
\hline 11 & $\begin{array}{l}\text { Ci yu tuo } \\
\text { 茨榆坨 }\end{array}$ & 6083 & 6083 & & 4281 & $70 \%$ & & 425 & 14.3 & 330 & $78 \%$ \\
\hline 12 & $\begin{array}{c}\text { Mu jia } \\
\text { 穆家 }\end{array}$ & 4544 & & 4544 & 3036 & $67 \%$ & & 278 & 16.3 & 200 & $72 \%$ \\
\hline 13 & $\begin{array}{l}\text { Ma jia } \\
\text { 馬家 }\end{array}$ & 2318 & 2318 & & 1538 & $66 \%$ & & 137 & 16.9 & 77 & $56 \%$ \\
\hline 14 & $\begin{array}{c}\text { Xi la la } \\
\text { 西拉拉 }\end{array}$ & 1453 & 1453 & & 839 & $58 \%$ & & 95 & 15.3 & 50 & $53 \%$ \\
\hline 15 & \begin{tabular}{|c|} 
Liujianfang \\
六間房 \\
\end{tabular} & 1932 & 1932 & & 963 & $50 \%$ & & 110 & 17.6 & 37 & $34 \%$ \\
\hline & Total & 56759 & 30738 & 26021 & 46569 & $82 \%$ & & 3939 & 1 & 3158 & $80 \%$ \\
\hline & Average & \begin{tabular}{|l|}
3784 \\
\end{tabular} & 1 & 1 & 3105 & 1 & & 263 & 14.1 & 211 & 1 \\
\hline
\end{tabular}

2016 年現在、尹家街道では、約 80\%の請負農家は一部又は全て の請負農地を貸出し、約 $82 \%$ の請負農地の土地流転が行なわれた。 土地流転が活発化した理由の 1 つして、潘北新区の中西部は遼河 （遼寧省中部を北から南へ向かって縦貫する大河）の沖積平野であり、 土壤は肥沃で、米が有名である。2009 年以降瀋北新区では、農地集 積と農業近代化を推進するために、畨場整備事業が行なわれ、灌溉 条件の悪い農地では電気井戸が整備され、営農条件がさらに改善さ れたことが挙げられる。

一方、集落ごとの農地区分について、街道の北部に位置する 3 朝 鮮族集落(曙光、永豊、創業)とその周辺の 8 漢民族集落(茨榆坨、馬 家、光栄、小営子、東拉拉、西拉拉、尹家、六間房)の全ての請負農 地は水田であり、南部に位置する 4 漢民族集落(穆家、下坎子、溝子 沿、新農)の全ての請負農地は畑である。統計からは、農地区分が土 地流転の比率に与えた影響は明らかではない(Table 4、Fig.3)。

\section{2 集落の類型化の概況}

ここでは、水田集落と畑地集落を分けて、集落の類型化の概況を 述べる(Table 5)。

\subsection{1 水田集落}

11 力所の水田集落のうち、3 集落(茨榆、光栄、東拉拉)では、離 農跡地は主に集落内の農家に貸出され、7 集落(小営子、馬家、西拉 拉、六間房、創業、曙光、永豊)では、離農跡地は主に集落外の農家 或いは合作社に貸出され、1 集落(尹家)で は、離農跡地は主に企業に貸出された。即 ち、3 集落は「集落内集積型」であり、7 集 落は「集落外貸出型」であり、1 集落は「企 業参入型」である。

\section{2 .2 畑地集落}

4 力所の畑地集落のうち、2 集落(下坎子、 溝子沿)では、離農跡地は主に集落内の農家 に貸出され、2 集落(穆家、新農)では、離農 跡地は主に集落外の農家に貸出された。即 ち、2 集落は「集落内集積型」であり、2 集 落は「集落外貸出型」である。

\section{4. 集落類型別の土地流転の仕組みの考察}

ここでは、集落類型別の土地流転の仕組 みとその事例を述べる(Table5 右側、Fig.3)

\section{1 集落内集積型}

\subsection{1 土地流転の仕組み}

3.2 節で述べたように、尹家街道では、3 力所の水田集落と 2 力所の畑地集落は「集 落内集積型」集落である。ヒアリング調査 によると、これらの集落では、通常に貸し 手農家と集落内の借り手農家・合作社の間 の協議が整った後、村民委員会(或いは農家 集団経済組織)注 13) も加えた三者で契約締 結を行う。村民委員会は、土地流転の発生 を公証、登録する。しかし一方、地縁関係・ 血縁関係に基づいて口頭契約で済ます場 合も多く存在する。 
Table 5 The ways of farmland liquidity and types of debtors in Yin Jia Subdistrict

尹家街道における土地流転の方式と借り手のタイプ

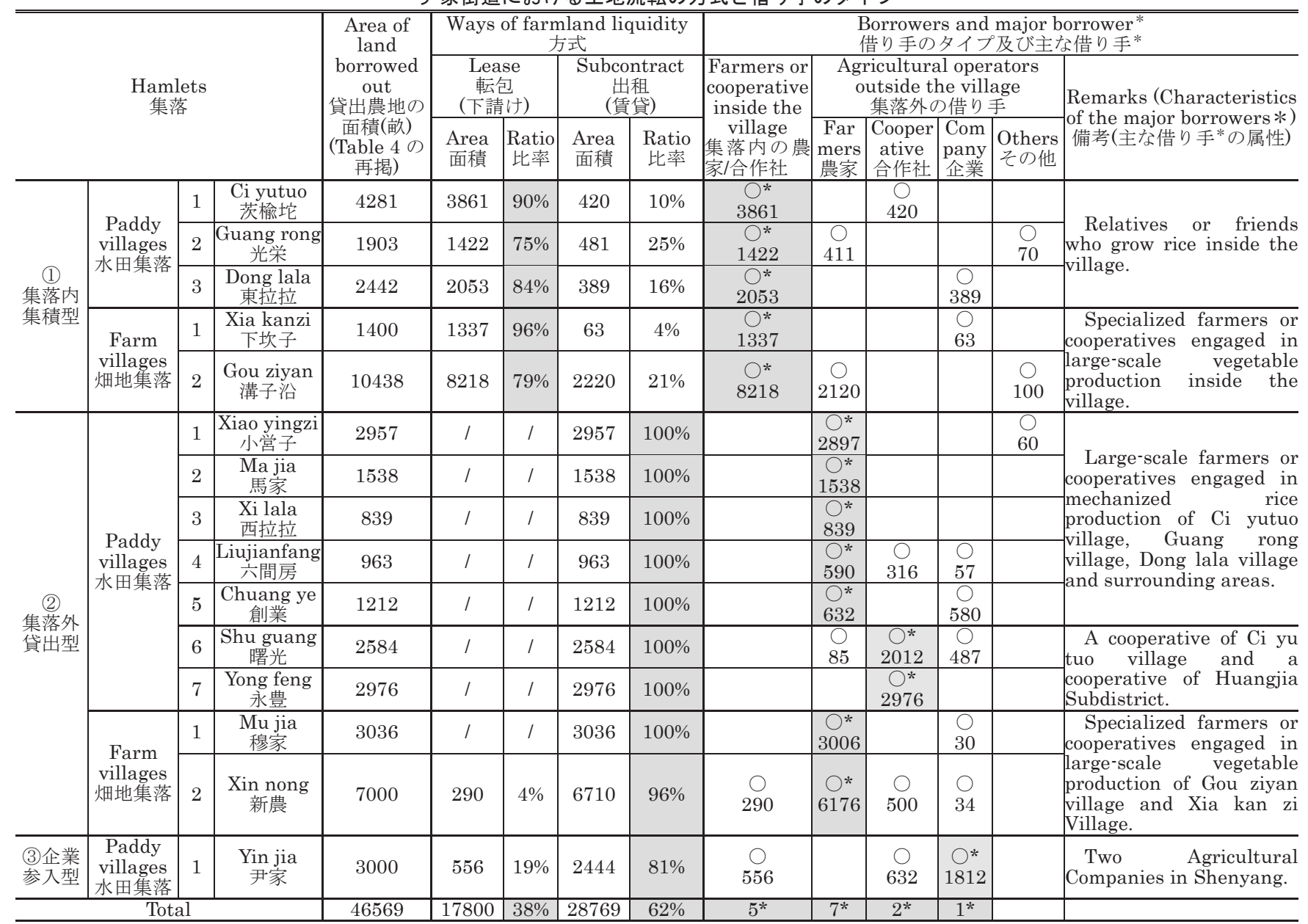

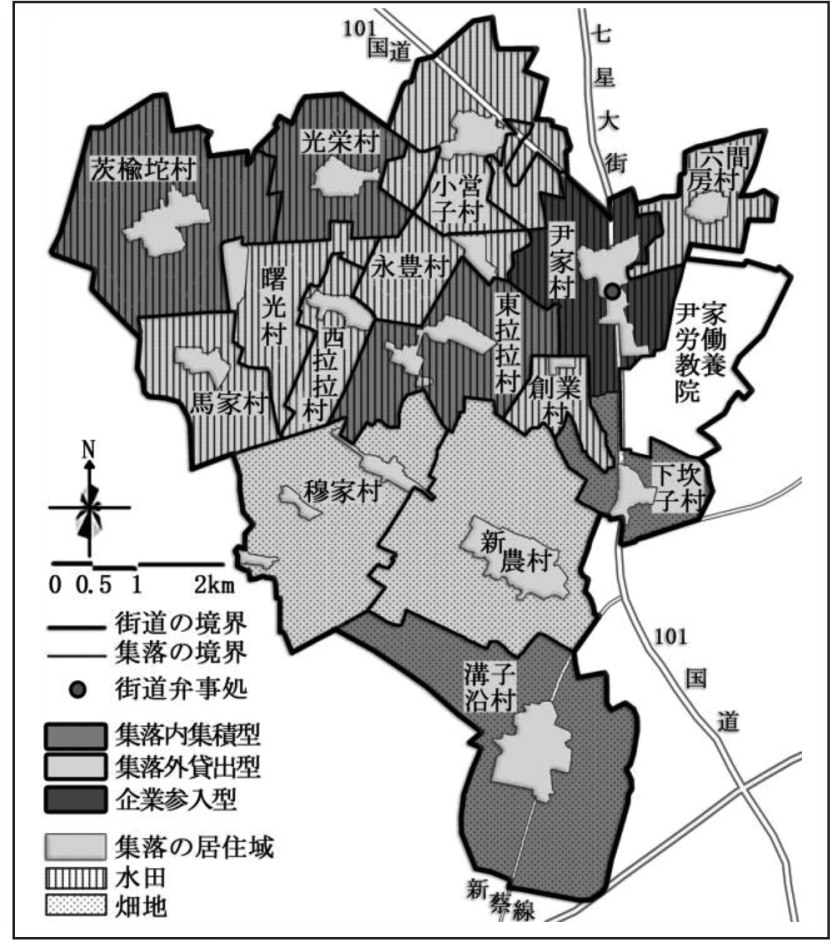

Fig.3 Distribution of different types of villages 集落類型別の空間分布

\section{1 .2 集落内集積型の事例}

【茨榆坨集落・水田集落】茨榆坨集落は尹家街道の西北部に位置 する。2000 年前後に土地流転が展開され、2010 年以降活発化して きた。離農農家は、土地を優先的に集落内の規模拡大志向のある親 戚・親族或いは知合いに貸し出す。本来 1 戸当たりの請負農地の面 積は $2.2 \sim 34.1$ 畧であるが、土地流転に伴い、100 欲以上の水田を 経営する稲作農家が増加してきた。また、2010 年以降農業機械(田 植機、コンバインハーベスター、トラクター等)を持つ農家が増加し、 積極的に経営規模の拡大を求好農家が少なくない。また、経営規 模が大きいほど、所有する農業機械の品質・価格が高くなる。

【溝子沿集落・畑地集落】溝子沿集落は尹家街道の南部に位置す る。2007 年以降大規模農家と合作社(千畧以上の野菜・花卉・穀物 の大規模栽培を行う)が現れ、離農跡地は主にこれらの大規模農家・ 合作社によって吸収された。また、これらの大規模農家・合作社は 借り入れた農地を経営すると同時に、野菜・花卉・穀物の生産に関 する機械化サービスも提供する。

\section{2 集落外貸出型}

\subsection{1 土地流転の仕組み}

ヒアリング調査によると、7 カ所の「集落外貸出型」水田集落で は、離農跡地は主に尹家街道の「集落内集積型」水田集落内或いは 尹家街道外潘北新区内の稲作農家・合作社に貸出された。2 カ所の 
「集落外貸出型」畑地集落では、離農跡地は主に「集落内集積型」 畑地集落内の大規模農家・合作社に貸出された。

集落外の農家・合作社に農地を貸出す場合、離農農家は借り手と の交涉、連絡を村民委員会に依頼する場合が多い。村民委員会、集 落外の借り手農家・合作社、貸し手農家の間の協議が整った後、街 道弁事処農業科の農地管理部門の公証証書による契約締結を行う。 しかし、地元の信頼関係に基づいて、農地管理部門の公証証書を求 めない場合も多く存在する。また、借り手は街道内の農家・合作社 である場合が多いが、街道外瀋北新区内の合作社である場合も見ら れた。貨貸借の期間は 5 年間の場合があり、農地の請負期(1998〜 2027/1999 2028)注14)の最後までの場合も多い。

\section{2 .2 集落外貸出型の事例}

【曙光集落と永豊集落・水田集落】曙光集落と永豊集落は尹家街 道の西北部に位置し、茨榆坨集落に隣接する。1990 年代半ばより、 朝鮮族の出稼ぎの展開に伴い、集落外一の土地流転が展開されてき て、2010 年前後すべての農地が集落外の稲作農家・合作社に貸出さ れた。曙光集落では、ほとんどの農地は茨榆坨集落の合作社に貸出 され、その合作社の構成員である 4 戸の大規模農家によって経営さ れている。また、集落の東北部の約 300 畧の農地は瀋北新区黄家街 道(尹家街道の東北部に位置する)の 1 つの合作社に貸出された。永 豊集落では、約 2000 畧の農地は茨榆坨集落の合作社に貸出され、 1000 畧の農地は上記の潘北新区黄家街道の合作社に貸出された。こ の 2 集落の村民委員会の構成員は、毎年の年末に借り手農家・合作 社から来年の借地料をもらい、個々の貸し手農家に分配する。

【新農集落・畑地集落】新農集落は尹家街道の南部に位置し、溝 子沿集落に隣接する。1990 年代半ばより瀋陽市の野菜生産基地(人 参、ジャガイモ等) となり、野菜生産専門集落として有名で、ほぼ全 ての農家は野菜生産を行う。しかし、2010 以降瀋陽市の市場開放度 の上昇に伴う他地域の野菜が輸入され、新農集落の野菜の市場競争 力が弱く、多くの農家が 離農した。現在、ほとんど の離農跡地は隣接集落・ 溝子沿集落の大規模農 家・合作社に貸出された。

\section{3 企業参入型}

\subsection{1 土地流転の仕組み}

尹家街道では、企業へ

の農地集積の試みは 2005 年以降、展開されてきた。 通常は企業が農地管理部 門で農地利用の需要を登 録し、農地管理部門は各 集落の村民委員会が提供 した農地利用の状況を確 認し、貸し手と借り手の 双方を連絡し、情報を提 供する。その後、企業、貸 し手農家、村民委員会の 間の協議が整った後、農 地管理部門の公証証書に

\section{よる契約締結を行う。}

街道弁事処が所在する尹家集落を始め、曙光、創業、下坎子、東 拉拉、穆家、六間房の 7 集落では企業への農地集積が見られた。す べての賃貸借の期間は農地の請負期(1998～2027/1999～2028)の最 後までである。貸出農地は畜産業、牧草生産、花卉・野菜生産、種 子生産の用地として利用されている。

\subsection{2 企業参入型の事例}

【尹家集落・水田集落】尹家集落は尹家街道の東北部に位置し、 尹家街道・街道弁事処の所在地である。101 国道が通っており、良 い交通条件を持つ。現在、離農跡地の主な借り手は瀋陽市の 2 つの 農業企業である(瀋陽市瀋北新区緑馨花卉園藝株式会社、835 歒、瀋 陽市于洪区玉峰花卉卸売センター、977 畧)。2 つの農業企業は、高 付加価值作物 (花・観葉植物、野菜など)の栽培を行うため、ビニール 八ウスを建てて、農地利用の空間的形態が従来の状態と大きく変わ った。

\section{5. 集落の類型化からみた集落・街道の計画課題}

ここでは、集落の類型化の視点から集落・街道の計画課題を展望 する。図 4 は集落の類型を郷級行政区の空間に投影し、郷域におけ る集落の類型化及び土地流転の仕組みを考察するものである。

11 か所の水田集落の内、 3 集落は「集落内集積型」であり、在籍 農家の離農離村の増加と同時に、営農規模拡大志向・力を持つ稲作 農家・合作社も増加し、離農跡地は主に集落内の稲作農家・合作社 によって吸収された。7 集落は「集落外貸出型」であり、在籍農家 の離農離村に伴い、離農跡地は主に尹家街道内の「集落内集積型」 水田集落内或いは尹家街道外瀋北新区内の規模拡大志向・力を持つ 稲作農家・合作社に貸出された。また、街道弁事処が所在する 1 集 落は「企業参入型」であり、離農跡地は主に 2 つの農業企業に貸出 され、高付加価值作物(花卉、野菜など)の栽培の用地となった。

\begin{tabular}{|c|c|c|c|c|c|}
\hline & $\begin{array}{l}\text { Types of villages } \\
\text { 集落の類型 }\end{array}$ & $\begin{array}{l}\text { ○Lenders } \\
\text { 。貸し手 }\end{array}$ & $\rightarrow$ •main browwers & $\begin{array}{c}\text { Responsibilities of } \\
\text { Villagers'Committees } \\
\text { 村民委員会の役割 }\end{array}$ & \begin{tabular}{|c|} 
Responsibilities of formland \\
management department \\
town government \\
街道の農地管理部門の役割
\end{tabular} \\
\hline \multirow{4}{*}{ 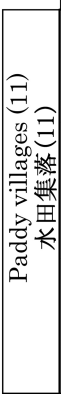 } & \multirow{2}{*}{ 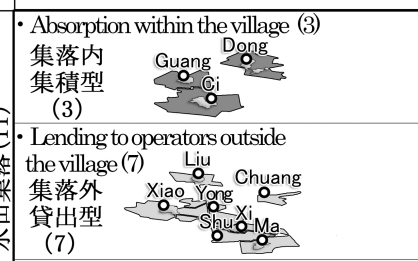 } & \begin{tabular}{|c|} 
oFarmers who \\
give upfarming \\
離農農家 \\
\end{tabular} & \multirow[t]{2}{*}{$\vec{A} \rightarrow \begin{array}{l}\begin{array}{l}\bullet \text { Farmers or } \\
\text { cooperatives } \\
\text { 農家/合作社 }\end{array} \\
\end{array}$} & $\begin{array}{l}\text { Notarizationand } \\
\text { registration } \\
\text { 公証、登録 }\end{array}$ & \\
\hline & & \begin{tabular}{|c|} 
oFarmers who \\
give upfarming \\
離農農家 \\
\end{tabular} & & $\begin{array}{l}\text { Negotiation and } \\
\text { contact } \\
\text { 交涉、連絡 }\end{array}$ & $\begin{array}{l}\text { Notarization and } \\
\text { registration } \\
\text { 公証、登録 }\end{array}$ \\
\hline & $\begin{array}{l}\text { - Agricultural company } \\
\text { intervention (1) }\end{array}$ & - Farmers who & - Company & \multirow{2}{*}{$\begin{array}{l}\text { Negotiation and } \\
\text { ontact } \\
\text { 交渉、連絡 }\end{array}$} & \multirow{2}{*}{\begin{tabular}{|l} 
Information collection and \\
publication, negotiation, contact, \\
notarization and registration \\
情報の収集 • 提供、交渉、 \\
連絡、公証、登録 \\
\end{tabular}} \\
\hline & 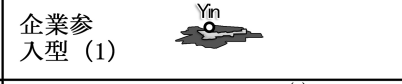 & \begin{tabular}{|c|} 
give up farming \\
離農農家
\end{tabular} & & & \\
\hline \multirow{2}{*}{ 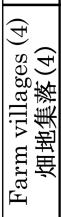 } & $\begin{array}{l}\text { - Absorption within the village (2) } \\
\text { 集落内 } \\
\text { 集積型 } \\
(2)\end{array}$ & \begin{tabular}{|c|} 
oFarmers who \\
give up farming \\
離農農家 \\
\end{tabular} & \multirow[t]{2}{*}{$\vec{\imath} \begin{array}{l}\begin{array}{l}\bullet \text { Farmers or } \\
\text { cooperatives } \\
\text { 農家/合作社 }\end{array} \\
\end{array}$} & $\begin{array}{l}\text { Notarization and } \\
\text { registration } \\
\text { 公証、登録 }\end{array}$ & \\
\hline & $\begin{array}{l}\text { - Lending to operators outside the village (2) } \\
\text { 集落外 } \\
\text { 劕出型 } \\
(2)\end{array}$ & 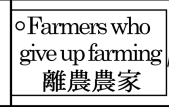 & & $\begin{array}{l}\text { Negotiation and } \\
\text { contact } \\
\text { 交渉、連絡 }\end{array}$ & $\begin{array}{l}\text { Notarization and } \\
\text { registration } \\
\text { 公証、登録 }\end{array}$ \\
\hline a & & 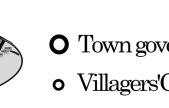 & ent & (或いは農家 & $\begin{array}{l}\text { 亿置する) } \\
\text { (経済組織) }\end{array}$ \\
\hline
\end{tabular}

Fig.4 Village type and the main subjects of farmland liquidity 集落の類型化と土地流転の仕組み 
4 力所の畑地集落の内、2 集落は「集落内集積型」であり、在籍農 家の離農離村の増加と同時に、野菜の大規模生産を行う農家・合作 社が現れ、離農跡地は主にこれらの農家・合作社によって吸収され た。他の 2 集落は「集落外貸出型」であり、離農跡地は主に尹家街 道内の「集落内集積型」畑地集落内の大規模農家・合作社に貸出さ れた。

このように、離農農家の増加に伴い、「集落内集積型」集落内の規 模拡大志向・力を持つ農家・合作社と農業参入企業は、郷域におけ る農地集積(農地の維持) と農業近代化の展開に重要な役割を果たし ていることがわかった。また、離農農家(貸し手) と集落内外の借り手 との合意形成を支えるために、村民委員会(公証、登録、交涉、連絡) と街道の農地管理部門(公証、登録、情報の収集・提供、交渉、連絡) が一定の役割を果たすこともわかった。

今後、戸籍農家の離農がさらに進展することが見込まれ、鄉域に おける農地維持と農業近代化を求めるために、鄉域内の規模拡大志 向・力を持つ農家・合作社を人力資源・社会資源として認識し、そ の情報システムの構築と活用が重要であると考える。そして、郷域 内の借り手が足りない場合、周辺地域内の規模拡大志向・力を持つ 農家・合作社や農業企業を活用することも必要である。従って、従 来の線引きと用途規制に注目した郷級土地利用総体計画には、土地 利用調整と農地維持に関する対応策に不備があり、土地利用調整の 仕組みを重視する郷級土地利用総体計画を建てることが重要である と考える。また、貸し手と借り手の合意形成(信頼関係の構築、双方 の利益の保護など)や農地利用の規制と指導(作物種類の規制、耕作 放棄と裏転用の禁止、干害と水害に関する技術対策と注意点など)に 関して、村民委員会と街道弁事処の農地管理部門の管理とサービス 機能を完備させることが重要であると考える。

一方、類型別集落の計画課題について、「集落内集積型」集落では、 農家離農の増加に伴い、一部の在籍農家の営農規模が増加してきて、 これらの規模拡大志向・力を持つ農家・合作社は集落・街道の農地 . 農業の維持に重要な役割を果たしており、その定着意思を強化する ための対応策が要請されている。「集落外貸出型」集落では、農地・ 農業の維持は主に集落外の農家・合作社に依頼しており、委託関係 の持続を求めるために、郷域内及び周辺地域内の規模拡大志向・力 を持つ農家・合作社や農業企業の存在とその特性を把握し、多様な 選択肢を用意することが必要である。「企業参入型」集落では、農地 利用の空間形態が大きく変わり、企業による農地の裏転用と耕作放 棄を監督することや、企業による賃貸借が終わった後、農地利用の 継続が課題になると考えられる。

また、尹家街道の離農農家の比率が高く、離農農家の職住関係の 変化とその定住・移住の動向が宅地の居住利用の持続に重要な影響 を与えることがいえる。そのため、離農農家の居住動向を把握し、 宅地の居住利用の持続に関する仕組みを整備することも重要な課題 となっている。例えば、集落外貸出型・曙光集落では、全ての在籍 農家が離農し、ほとんどの労㗢力が都市部或いは韓国で出稼ぎをし ており、挙家離村が非常に多い。他集落の農村住民と都市住民の宅 地(住居)需要に応じて、宅地の利用・管理の持続を求めることが必要 となっている。一方、企業参入型・尹家集落では、ほとんどの在籍 農家が離農したが、40 歳以上の多くの労働力が近くの都市的地域で 出稼ぎをしており、集落内で在住している。周辺地域における農外
就業機会の確保が宅地の居住利用の持続に必要であるといえる。

\section{6. まとめと展望}

\section{1 まとめ}

本研究では、中国遼寧省瀋陽市瀋北新区・尹家街道を対象に、土 地流転に関する制度的・地域的背景を把握したうえで、郷級行政区 域における農村集落の土地流転の実態を考察し、集落の類型の特性 及び今後の計画課題を検討した。今回の研究により以下のことが分 かった。

(1)中国農村では、在籍農家の離農離村と土地流転の進展に伴い、 集落の農地経営の実態と担い手像が大きく変化し、集落の展開方向 と今後の計画課題を再認識することが重要な課題となっている。

(2)対象地域・尹家街道では、2016 年現在、約 $80 \%$ の請負農家は 一部又は全ての請負農地を貸出し、約 $82 \%$ の請負農地の土地流転 が行なわれた。

(3)尹家街道の 15 集落の内、 11 集落は水田集落であり、4 集落は 畑地集落である。11 カ所の水田集落のうち、3 集落は「集落内集積 型」であり、7 集落は「集落外貸出型」であり、 1 集落は「企業参入 型」である。4 力所の畑地集落のうち、2 集落は「集落内集積型」 であり、2 集落は「集落外貸出型」である。

3 力所の「集落内集積型」水田集落では、在籍農家の離農離村の 増加と同時に、営農規模拡大志向 - 力を持つ稲作農家・合作社も増 えてきて、離農跡地は主に集落内の稲作農家・合作社によって吸収 された。7 カ所の「集落外貸出型」水田集落では、在籍農家の離農 離村に伴い、離農跡地は主に尹家街道内の「集落内集積型」水田集 落内或いは尹家街道外瀋北新区内の規模拡大志向・力を持つ稲作農 家・合作社に貸出された。1 カ所の「企業参入型」集落では、離農 跡地は主に 2 つの農業企業に貸出され、高付加価值作物(花・観葉植 物、野菜など)の栽培の用地となった。

2 力所の「集落内集積型」畑地集落では、在籍農家の離農離村の 増加と同時に、野菜の大規模生産を行う農家・合作社が現れてきて、 離農跡地は主にこれらの農家・合作社によって吸収された。2 力所 の「集落外貸出型」畑地集落では、離農跡地は主に「集落内集積型」 烟地集落内の大規模農家・合作社に貸出された。

\section{2 展望}

ここでは、上記の知見を踏まえ、郷域における類型別集落の位置 付けと今後の計画課題の展望を述べる。

尹家街道では、「集落内集積型」集落内の規模拡大志向・力を持つ 農家・合作社は「集落外貸出型」集落内の離農跡地の集積に重要な 役割を果たしており、農業企業は「企業参入型」集落内の多くの農 地を経営している。即ち、現段階の集落は人民公社期の閉鎖的なも のと大きく異なり、離農跡地の維持を求めるために、集落内の農地 集積と集落域を超える土地流転が普遍的な状況となっている。その 中で、村民委員会と街道の農地管理部門が一定の役割を果たしてい る。このように、郷域の農村計画において、在籍農家の離農のスピ 一ドに合わせて、郷域内と周辺地域内の規模拡大志向・力を持つ農 家・合作社や企業を人力資源・社会資源として認識し、情報システ ムの構築・活用によって、郷域全体の農地維持と農業近代化を求め る仕組みの整備が重要である。即ち、土地利用調整の仕組みを重視 する郷級土地利用総体計画を建てることが必要となっている。また、 
貸し手と借り手の合意形成や農地利用の規制・指導に関して、村民 委員会と街道弁事処の農地管理部門の管理とサービス機能を完備さ せることも重要であると考える。

一方、集落計画(土地・空間資源の維持計画)において、在籍農家の 離農のスピードと集落内外の規模拡大志向 - 力を持つ農家 - 合作社 や農業企業の存在に応じて、農地・農業の維持を求める施策が必要 である。また、在籍農家の職住関係の変化と定住・移住の実態に応 じて、宅地の居住持続を確保する仕組みの整備も課題となっている。

\section{謝辞}

本研究の現地調查を進めるにあたり、中国東北大学建築学院曲藝 研究室の曲藝副教授と大学院生、中国遼寧省瀋陽市瀋北新区尹家街 道の農業科の公務員王立嬌様、調查対象集落の居住者の皆様にご協 カいただきました。また、本稿の作成にあたり、神戸大学山崎研究 室の山口秀文助教からのご助言をいただきました。ここに記して謝 意を表します。

\section{参考文献}

1) Yue Zhang: The Will and Its Explanation on Farmland Transfer of the Farmers-Empirical Analysis Based on the Survey Data of 1000 Farmers in 10 Provinces-, Issues in Agricultural Economy, pp.64-70+111, 2010.2 (in Chinese)

楽章：農民の土地流転の願望及びその解釈一十か省の千戸の農民に対した 調査データの実証分析により-，農業経済問題， pp. 64-70+111，2010.2

2) Yuan Qifeng, Chen Shifeng: Review and Prospect of the Research on the Construction of First-level Disciplines in Urban and Rural Planning, Planners, pp.5-10, 2012.9 (in Chinese)

袁奇峰・陳世棟：城郷計画一級学科建設の研究述評と展望, 計画師, pp. 5$10, \quad 2012.9$.

3) Huang Zuhui, Wang Peng: Farmland Transfer and Its Impacts on the Development of Modern Agriculture: Status, Problems and Solutions, Journal of Zhejiang University (Humanities and Social Sciences), pp.3847, 2008.3 (in Chinese)

黄祖輝・王朋：農村の土地流転 : 現状、問題及び対策-土地流転の現代農業 発展に対する影響-, 浙江大学学報 (人文社会科学版), pp. 38-47, 2008.3

4) Bao Zongshun and three other person: The Regional Differences and Affecting Factors of Farmland Transfer-A Case Study of Jiangsu Province-, Chinese Rural Economy, pp.23-30+47, 2009.4 (in Chinese) 包宗順ほか 3 名：農村の土地流転の区域的差異及びその影響要素-江蘇省 を事例に-, 中国農村経済, pp. 23-30+47, 2009. 4

5) Mei Lin: Study on the Mode of Rural Land Transfer in China, FuJian Normao University, Doctoral Dissertation (Agricultural Economics), 2011 (in Chinese)

梅琳：わが国における農村の土地流通のモデルに関する研究, 福建師範大 学, 博士学位論文(農業経済学分野), 2011

6) LI Yinghua, ITO Ryoji, AOYAGI Hitoshi: Liquidization of the Farmlands Located in Chinese Farming Villages Vacated by Migrating Citizens : A Study of Village H, Jixi City, Heilongjiang Province, Journal of rural problem 47(1), pp.108-113, 2011.6 (in Japanese)

李英花・伊藤亮司・青柳斉：中国出稼ぎ農村における農地流動化の特徴と 展望: 黒龍江省鶏西市 $H$ 村の事例から, 農林業問題研究 47 (1), pp. 108-113, 2011.6

7) JIN Honglan, FUJISHINA Tomoumi, OZAWA Wataru: Present Condition and Problems of the Rural Land Circulation in Yanbian, China, Agricultural Management Research 51(1), pp.119-124, 2013.6 (in Japanese)

金紅蘭・藤科智海・小沢瓦: 中国延辺地域における農地流動化の実態と課題： 図們市Ｙ鎮のＭ 村とQ 村を事例として, 農業経営研究 51 (1), pp. 119-124, 2013. 6

8) Li Xuelian, Piao Hong, Sakashita Akihiko: Farmland adjustment due to migration of ethnic Koreans in Northeast China, The frontiers of agricultural economics 19(1), pp.32-46, 2016.4 (in Japanese) 李雪蓮・朴紅・坂下明彦：中国東北地方における朝鮮族出稼ぎによる集落 の農地移動調整, フロンティア農業経済研究 19(1), pp. 32-46, 2016.4

9) Committee of Learning and Publicity on Literature and History within CPPCC Shenyang Committee, CPPCC Shenbei New Area Committee: Shenyang place names - Shenbei New Area Volume, Shenyang Publishing House, 2014 (in Chinese)

政協潘陽市委員会学習宣伝文史委員会・政協潘北新区委員会: 潘陽地名・瀋 北新区巻，瀋陽出版社，2014

10) Sun Yan and three other person: Spatial Structure Evolution of Urban Land Use in Shenyang during 1910-2010, Progress in Geography, pp.1204-1211, 2012.9 (in Chinese)

孫雁ほか 3 名：1910-2010 年瀋陽市における都市的土地利用の空間構造の 変容とその特徵, 地理科学進展, 31(09), pp. 1204-1211, 2012.9

注

注 1) 中国農村の土地流転 (動名詞) は、農村の土地(農地、宅地、集団建設用 地）の利用権或いは経営権の流通を意味する。中国では、2008 年以降、農地 の土地流転に関する制度・政策は続々と打ち出されており、完備されつつ あるが、宅地と集団建設用地の土地流転に関する制度・政策はまだ模索段 階である。本稿では、土地流転は農地の土地流転を指す。

注 2）国務院新聞弁公室、「農村の土地の所有権・請負権・経営権の分離方法 に関する意見」に対する韓長賦の回答、中華人民共和国農業農村部ホーム ページ、http://www. moa.gov. cn/xw/qg/201611/t20161104_5350207.htm

注 3） 区は市の下に設置している行政組織で、新区は国、地方又は都市の新 たな発展戦略に対応して、郊外に新たに建設或いは再整備・再開発された 区である。潘北新区は潘陽市の都心部を発展拡大させる為に、都市近郊地 域を再開発した区である。

注 4）郷級行政区は農村部の行政管理の基礎単位であり、郷・鎮・街道の 3 種 類がある。

注 5）全国の土地流転の統計データ、土流網参考 (2019 年 9 月 20 日)、 https://www. tuliu. com/data/nationalProgress. html

注 6）新中国成立後、工業化・都市化優先の発展戦略のもとで、都市計画学の 発展が重視され、農村計画学の発展が軽視された。2005 年 10 月に中国共 産党第 16 期中央委員会第 5 回全体会議では「社会主義新農村建設」、「都市 と農村の統一的発展」が打ち出され、農村計画理論の構築が注目されるよ らになった。2011 年 3 月に中国教育部が公布した「学位授予和人才培养目 录 (2011 年)」(学位授与および人材育成学科一覧 2011 年)により、都市計 画学は都市と農村計画学 (城郷規劃学) に変名され、一級学科になり、その 下で、農村計画分野が設置された。

注 7) 下記の行政組織の概略図を参考

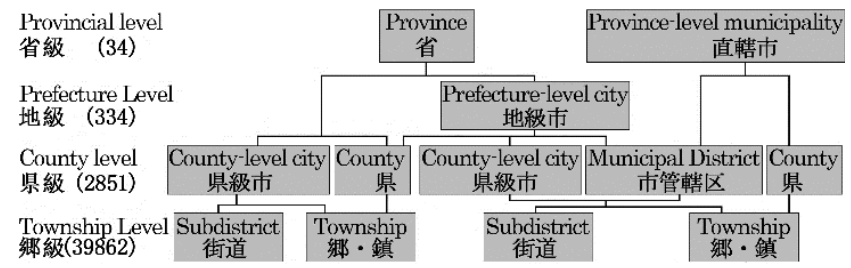

※「中国統計年鑑 2017」参考

※概略図であり、民族自治地域、特別行政区の組織構造は省略している。

注 8） 1992 年に中韓国交正常化以降、朝鮮族人は韓国や韓国企業が集中する 沿海都市部への出稼ぎが相次ぎ、加えて韓国人との国際結婚及び親族訪問 による長期出稼ぎが活発化になった。

注 9）「闖関東」は清朝に行われた山東省、河北省、河南省、山西省に棲む中 国人（特に漢民族）の東北地方への民族移動を指す。

注 10）瀋陽市瀋北新区における大規模な農村の土地の経営権流通の試験地点, 中国農業情報網参考、http://www. agri.cn/V20/ZX/qgxxlb_1/qg/201708/t2 0170809_5779733.htm

注 11）瀋北新区では、農民専業合作社は一般的に一戸から数戸の農家によっ て運営され、集落内及び周辺地域内の作業委託、農地委託を受ける。それ は、中国広東省南海区の土地株式合作社に基づく「南海モデル」の「農家 が自らの意思で農地の請負経営権を株式の取得の形で出資し、農地をプー ルして、共同経営を行う」という運営の仕方と大きく異なる。

注 12）「農村土地請負経営権流転管理弁法」（21 条、農業部）により、土地 流転における貸し手と借り手は協議して合意を得る上で、契約書を作成す 
ることが必要である。貸し手、借り手、農家集団組織、郷級政府機関の農 村土地管理部門、4 つの主体それぞれが 1 つの契約書を保管する。ちなみ に、一年以内の作業委託の場合、集落内部の土地流転の場合、契約書は必 須書類ではない。

注 13）中国の「土地管理法」により、農村の集団所有土地は農家集団経済組 織或いは村民委員会によって経営・管理する(第 10 条)。

注 14）尹家街道では、第二回の農地の請負期について、一部の集落は1998 か ら 2027 までであり、一部の集落は 1999 から 2028 までである。 
STUDY ON THE DIFFERENTIATION OF VILLAGE TYPES AND PROBLEMS

ON VILLAGE PLANNING BASED ON FARMLAND LIQUIDITY IN NORTHEAST CHINA

- A case study of yinjia sub district in shenbei new district, shenyang city, liaoning province -

\section{Ran $Z_{H A N G}{ }^{* 1}$ and Juichi YAMAZAKI*2 \\ ${ }^{* 1}$ Ph.D. Candidate, Graduate School of Eng., Kobe Univ. \\ *2 Prof., Graduate School of Eng., Kobe Univ., Dr.Eng.}

Taking Yinjia Subdistrict in Shenbei New District, Shenyang City, Liaoning Province as an object for research, this paper aims to clarify the actual situation of farmland liquidity in all the villages of a township, explore the tendency of village differentiation, and put forward the rural planning problems to be faced in the future in China.

In this paper, we set the following three research topics

1) Based on the relevant information and statistical data of land transfer obtained by Yinjia Street Office, this paper analyses the actual situation of land transfer, explore the tendency of village differentiation and the orientation of each type of village.

2) Based on the investigation of civil servants in Yinjia Subdistrict office and residents in the case villages, we grasped the actual progress of land transfer in various types of villages.

3) On the basis of the above two topics, this paper puts forward the development direction and orientation of different types of villages in Yinjia Subdistrict and the subject of rural planning in the future.

According these research topics, we conducted field surveys from September to November 2017, October to November 2018, and the results are as follows.

(1) In China's rural areas, with the population outflow and the promotion of land transfer, the operation status of agricultural land and the composition of farmers in rural villages have undergone considerable changes. Therefore, it is extremely important to recognize the direction of development of villages and future planning topics.

(2) In 2016, about 80 percent of farmers lent part or all of their land to other agricultural operators, and about 82 percent of farmland in Yinjia Subdistrict was lent out.

(3) There are two ways of land transfer, absorption within the village or lend it to operators outside the village.

(4) Of all the farmland transferred out, $38 \%$ was lent to farmers inside the village, and $62 \%$ to agricultural operators outside villages.

(5) Based on the major object of land transfer, all the 15 villages can be divided into three types: "Absorption within the village type", "Lending to operators outside the village type", and "Agricultural company intervention type".

Large-scale peasant households and cooperatives in "Absorption within the village type" villages play an important role in the large-scale management of agricultural land and the development of agricultural modernization in Yinjia Subdistrict.

Based on these findings, we point out that we should recognize the role of a village from the perspective of regional integration in the future. 